\title{
WHY WE NEEDED A THIRD DUTCH TRANSLATION OF ULYSSES
}

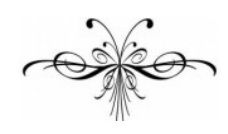

\section{ERIK BINDERVOET \& ROBBERT-JAN HENKES}

\begin{abstract}
In 2012, we published Ulixes, our translation of James Joyce' Ulysses. In this lighthearted, nitpicking, unsparing article we take a closer look at their two Dutch predecessors, Vandenbergh (1969) and Cleas \& Nys (1994), and explain why a new translation was badly needed. The main objection is one of tone and music. Ulysses, 'a gobelin depicting the world in a day' was, in their words, "made into a doormat with the message "welcome" in the previous Dutch translations. Lacking is the richness, the uncompromising unicity of the Joycean style. Both translations flatten and dumb and dim down to a large extent. They may be Dutch, but they are not Joycean. Vandenbergh in 1969 pioneered his way through a still hardly understood book, and his translation, while prone to errors and halting prose, in its enthousiasm captures the explorative reading process better than his followers do, Claes and Nys, who more often than not choose the most simple Dutch equivalent they can find for even the uncommonest Ulyssean words. In both cases the result is disastrous for a right appreciation of the book. In a series of examples, taken from the Sirens episode, and from a
\end{abstract}

Resumo: Em 2012 publicamos Ulixes, nossa tradução do Ulysses de James Joyce. Neste artigo, leve, pródigo e procurador de defeitos, nos detemos sobre seus dois predecessores holandeses, Vandenbergh (1969) e Cleas \& Nys (1994), e explicamos por que uma nova tradução se mostrava muito necessária. A principal objeção àquelas diz respeito ao tom $\mathrm{e}$ à música. Ulysses, "um gobelino a representar o mundo em um dia" foi, por meio das palavras das traduções holandesas, "tornado um capacho com a mensagem "bem-vindo"'. Faltam a riqueza e a unicidade nãonegociável do estilo joyceano. Ambas as traduções foram, em grande medida, niveladas por baixo e tornadas pálidas e menos exigentes intelectualmente. Elas podem ser holandesas, mas não são joyceanas. Em 1969, Vandenbergh desbravou um livro ainda muito pouco compreendido e sua tradução, ainda que tendente a erros e de uma prosa hesitante, captura, em seu entusiasmo, o exploratório processo de leitura melhor do que seus sucessores, Claes and Nys, que, com muita frequência, escolheram os equivalentes holandeses mais simples que puderam encontrar, até mesmo para as palavras ulisseanas mais in- 
renewed visit of the famous 'Sandwich' passage (see Scientia Traductionis n.8, 2010), we put the finger on the hurtful spot, as the Dutch saying goes. We discuss the difficulty of translating puns, rhymes, allusions and in passing formulate some general criteria to which a (any) translation of Ulysses should comply.

Keywords: Allusions; Comparative Translation Studies; Rhymes; Translation Practice; Ulysses.

\begin{abstract}
comuns. Nos dois casos o resultado é desastroso para uma apreciação correta do livro. Através de uma série de exemplos tirados do episódio Sirens, e de uma nova visita à famosa passagem do "Sanduíche" (ver Scientia Traductionis, n.8, 2010), colocamos o dedo na ferida, como diz o ditado holandês. Discutimos a dificuldade de se traduzir trocadilhos, rimas, alusões, e, de passagem, formulamos alguns critérios gerais que (qualquer) tradução do Ulysses deve cumprir.
\end{abstract}

Palavras-chave: Alusões; Estudos da Tradução Comparados; Rimas; Prática de Tradução; Ulysses.

$\mathrm{I}$ n 2007, we went to Dublin to partake in an experimental linguistic transformation in a contemporary setting: we went to celebrate Bloomsday on the steps of the James Joyce Centre in the North Great George's Street, looking out onto Belvedere College at the far end, the place where Joyce tackled Aristotle and tussled with Aquinas. We were supposed to read, in our own famously incomprehensible and, as some Englishmen even suspect, non-existent language, a selected passage from Ulysses, along with a polyglot company from all over the world, among which a fair corps of ambassadors, a frail female singer (the Irish entry for the Eurovision Song Contest) and a bevvy of professional Leopold Bloom impersonators. All under the auspices of lots and lots of sunshine behind the drizzly, grizzly clouds.

In the Netherlands we are twice blessed with two translations of Joyce's masterpiece, which is a wonderful thing. There are by now more than thirty translations of Hamlet in Dutch, so Ulysses still has a long way to go, but in general, the more translations, the better. Let a thousand flowers blossom, even if they are dead nettles! Non-native speakers can have their choice of translations: the English-speaking peoples on the contrary forever will have to make do with the single one and only, eternal original. We were sorry for them, and we told them so, in Dublin, that afternoon, plainly, to be answered by a murmur of approval and appreciative laughter from the thickly clad and eagerly listening crowds. And while all around us the hilarious Anglo-Irish original resounded, in manifold accents from all over the world, laced with translated passages in the Japanese, Chinese, Spanish and Latvian, we abused the Dublin hospitality by turning our allotted time into an ad hoc translation workshop, by reading from both Dutch translations alternatively, to find out, in the lion's or horse's mouth as it were, by proof of fire and water, which one sounded more authentically Joycean to Dublin ears, on Dublin soil, against the backdrop of the Blue Book of Eccles itself. 


\section{WHY WE NEEDED A THIRD DUTCH TRANSLATION OF ULYSSES}

And it may be our fault, but neither of them did. Both sounded pretty poorly, to be absolutely blunt about it. They sounded like Ulysses about as much as statues of Joyce look like Joyce. Like the two in Dublin. The one is affectionately called 'the prick with the stick', and the other, on Stephen's Green, is the head of a man looking in agony while his own emaciated hand is trying to strangle him. From afar, at first, you think: Hey, is that Joyce? But when you come closer, you think: No, it isn't. And then you read the explanatory plaquette underneath, and then still, it's supposed to be him! James fucking Joyce! The same happens in Disneyland: You think you come across Donald Duck, but it's just a jerk dressed up in a duck suit.

Our two previous Dutch translations resembled the original in the same way. It says James Joyce, Ulysses on the cover, but inside it is something else: bland, bleak, halting Dutch as opposed to rich, flowing, sensual English. Yes, of course, traduire, c'est trahir un peu, but to make a doormat with the message "welcome" out of a gobelin depicting the world in a day decidely goes too far. In Dublin, even the mumbling and stumbling stonecoal English from the Norwegian ambassador came closer to conveying the musical prose of Joyce than our two cloggy heavyfooted efforts.

Is it the bane of every translation to fail and fail worse? Maybe a translation at first sight necessarily is discomforting and disappointing, in its uphill battle with the cherished original itself, especially when the original is linguistically as rich as the richest dark Guinness ale and can be read aloud with so much gusto and spittle as it was, that day. But a good translation should be able to overcome that disadvantage after some pages, and hold its own, and lead its desperate separate existence, not displacing the original, but alongside it.

What is it that makes the 1969 and 1994 translations of Ulysses inadequate in our eyes? First, it should be made clear that Ulysses is a book that thrives on more translations and retranslations. New translations only add to the experience, to the depth. With one translation, the comparison is with the original. With two, with the original and with the other translation. The wonderful world of Ulysses becomes only the more 3D with more translations. Happy the human bean proficient and accomplished in more languages: he (who is in many cases a she) can walk through Ulysses in many different worlds at the same time.

Ulysses (this is no big secret) is eminently a book of rereading. Ulysses isn't read, it is reread, and rereread. (Or lain aside and left unfinished, as all works of art, as Paul Valery has it.) It is a book, so complex, with so many details and nuances, in which every letter is worth its weight in gold, myrrh and frankincense, that a reader and rereader will always dicover new vistas in it, unseen parallels and nuances that escaped his attention at an earlier reading.

Both Dutch Ulysses mammoth efforts have many things going for them. Vandenbergh in 1969 was hailed as a "pioneer", although by then Ulysses must have been translated about a dozen times worldwide. The first Dutchman to climb the Eiffel Tower, that kind of adventurous pioneering. But Vandenbergh's translation is catching in its enthusiasm, and in his often uncertain solutions that, as it were, repeat the process of reading Ulysses itself. Vandenbergh doesn't know too well what he is saying, and in a way this groping in the dark 


\section{ERIK BINDERVOET \& ROBBERT-JAN HENKES}

belongs inalienably to Ulysses, based as the book is on the Principle of Uncertainty. The sticker that was handed out in 1969 to every buyer of the Dutch Ulysses, saying Ik heb Ulysses helemaal gelezen, "I read Ulysses from beginning to end", conveyed the enthusiasm at the time, but the wobbly result would have been better excerpted with a bonus sticker Maar ik snapte er geen hol van, "But I didn't quite get it."

The second translation, in contradistinction, is very sure of itself, and of improving on Vandenbergh: everything is made understandable, even more so than in English. The tone is offhand, the impression is one of superb, arrogant ease, textual problems disappear because they are not seen. In translating out-of-the-way words, they invariably choose a more bland Dutch equivalent, often the first equivalent listed in the Dictionary. This happens in the first lines for instance with "plump" and "fearful": their dik and bang are so bleak as to be almost parasitical. If Joyce wanted to write "fat" and "scared", he probably would have found the right words. The monologue intérieur in their hands becomes a series of filled-in grammatical sentences, with now and then an elided pronoun, first personal singular ( $i k$ becoming ' $k$ ), or definite article (het becoming ' $t$ ) to show that something is going on, or at least give that impression. They have no ear for music; "Eumaeus" they translated in grammatical, proper, clean, only slightly faulty Dutch, not much different from the rest of the book and their preferred style of translating, and a far cry from the Catalogus Errorum in which every sentence is at fault; there is no attempt in the "Oxen of the Sun" chapter to follow whatever development of prose literature. On every page the reader will ask himself, occasion after occasion: why on earth did or would Joyce write such a journalist sentence down, with only the bare statement. And why on earth would I want to read this? Most readers in Dutch stop reading the translation, they don't stop reading Ulysses. But when this wondering, clueless, bored reader will revert to the English, he will find out that Joyce on each and every occasion most certainly made a sentence that was telling and beautiful at the same time, more meaningful than the "to get on with the story" layer that Claes and Nys managed to grasp. Their translation lacks everything which makes Ulysses into the richest and funniest book on earth (except maybe bits of Finnegans Wake).

We will now take a closer, close-reading look at an assorted passage, the famous Sandwich-sequence, and see what wideopen windows of opportunity the previous translations give us for a fresh, new, better, more Joycean translation. We will dissect the passage from a purely practical point of view, as openminded fellow-translators that are no better than they should be, nor worse, and loyal to the only thing they should be loyal to - that is, their author and the book he wrote. And to the language they translate into. Two things they should be loyal to. But first let's have some music. Tadaa!

\section{Musical intermezzo}

In the "Sirens" episode, we have music in horns of plenty. To make the conversion of sound to music, is the great task Joyce set himself, and in Sirens, just as letters become words, the sounds become music. But there's a snag: the meaninglessness of music, the inexpressible whatness or whatisitaboutness, 


\section{WHY WE NEEDED A THIRD DUTCH TRANSLATION OF ULYSSES}

does not pertain to the words Joyce chooses. It is not mere sounds he produces: whatever he writes, even the most obvious onomatopeia, always means something. What follows are a few random examples, a couple of musical snippets. They are random because we didn't choose them ourselves, we didn't go out hunting for blaring glaring staring you in the face inadequacies in the translations of our esteemed predecessors to wave them about here. No, unbeknownst to us, these examples were handpicked and chosen by Fritz Senn and Erika Mihálycsa for reasons of their specific difficulties of untranslatability, to be discussed during the Zürich Transwork translatorial workshop in May 2010, that we were honoured to be allowed to attend.

Tipping her tepping her tapping her topping her. Tup. (11.706-7)

Pure Musicke! And the opportunity to make a delicate, miniature beautiful soundscape.

Vandenbergh (319): Haar dikkend, dakkend, dokkend, dekkend. D'rop bok. Dikken en dakken refer ever so lightly to a children's song, but with no picture to spring to mind from it. Literally, only dekkend means anything, it's what stallions do to mares in order to procreate. And d'rop bok would mean that the he-goat jumps hop on it. Unhappy present participles abound, which in Dutch are considered plain ugly or rather anglicistic. This does not say everything, of course, but here the necessity to use them is far from clear.

Claes \& Nys (293): Haar bonzen haar boren haar broeken haar bruiken. Bonk. This uses infinitives, which is better, but what is worse is that it doesn't have any sound at all anymore, let alone music: they come up with a row of disconnected words that merely alliterate, and are all the more disjointed because the third word broeken is not an infinitive anymore, but the plural of broek, trousers. And what bruiken is, the reader can only guess: another plural? A case of acute alliteritis? But bruik is no word. An infinitive, an invented shortening of gebruiken use? Yes, bonken and bonzen have connotaions of the sexual act, but in Dutch (as in any language probably), all words can be directed towards sexual innuendo, or even enuendo, it's just how leeringly you want to read it. The challenge here is to have 1) the music, 2) the meaning, which is mostly 3 ) the innuendo. And it is possible!

Because, in Tikkelt haar tekkelt haar takkelt haar tokkelt haar. Tuk, we have the sound fairly well taken care of, and the meaning, videlicet the innuendo as well: tikkelen is to tickle, tekkelen comes from teckel and is a dachshund, in which word the visualisation of the wellknown so-called dog-position in lovemaking lies around the corner, takkelen can be read as to tackle somebody, a violent way of making girls who say no do yes, tokkelen is Dutch black (Surinam) slang for talking but it also means strumming the snare instruments, again no far cry from strokingly strumming a beloved one, while the last word, Tuk, fits the entire picture and sums it up: to have someone tuk is to have fooled him, to be tuk on something is to be very fond of it, and Tuk is the name of one of the first Dutch porn magazines in the Sixties, the word being an anagram of the ordinary, colloquial, vulgo vulgar Dutch word for the female reproductive organ, the kut. Plus, tök (pronounced $t u k$ ) is, we were discreetly informed, the Hungarian word for testicles or hairy balls or hirsute nuts. So there you are. 


\section{ERIK BINDERVOET \& ROBBERT-JAN HENKES}

Jog jig jogged stopped. Dandy tan shoe of dandy Boylan socks skyblue clocks came light to earth. (11.977)

Jig jog. There are many ways to translate the sound of the jogging of the horse pulling the Irish jaunting car. But to choose which one entails an awareness of each and every instant it is used, to make sure it fits everywhere, also in places where the jig and the jug may refer to the sexual enactment. And there lies the rug, as Shakespeare almost said. Dutch jaunting cars can go hosseklos, holderdebolder, hotsebotse, and as intimated above, in Dutch there can be sexual innuendos everywhere, especially in these onomatopoetics. In the second sentence, annotator Don Gifford tells us, a nursery rhyme is hidden: "Handy dandy, sugar and candy." So a translation would have at least to sound like a nursery rhyme, irrespective if it actually exists or not. Plus, in the musical sphere, there is the rhyme "clocks" and "socks" - easy: in Dutch it is klokken and sokken - but, curiously, neither Vandenbergh nor Claes \& Nys gave the rhyme its due.

Vandenbergh (328): Rinkinksukkelrijden stopte dandyachtige bruine schoen van dandy Boylan sokken hemelsblauwe klink keerde licht tot de aarde terug. The translator telescopes the wellchosen two sentences into one, not stopping, as Joyce does, but fearlessly going on, losing the halting, expressed in the words themselves. The awkward dandyachtige (dandylike) is too long, and: no rhyme, nursery or otherwise...

Claes \& Nys (301): Gehotsebots stopte plots. Beige dandyschoen van dandy Boylan sok hemelsblauw motief kwam met lichte tik neer op de grond. The absence of the socks-clocks rhyme leaves the door agape for improvement. Our first version was:

Sjok sjik sjokken stopte. Dandy tanen schoen van dandy Boylan sokken hemelsblauwe klokken brachten zich licht ter aarde. The tan shoe is a poser: we can make it tanen, lichtbruin, or beige. Best would be tanen but this word is mainly used for the colour, and the feel, of the skin of people who have been long at sea. So it became beige, because lichtbruin is too long. Maybe the Dutch Boylan will have to wear slightly differently coloured shoes, but what the heck: we'll do our movie in glorious black-and-white in any case. And sjokken is more what humans do, sauntering, while something like hossebossen is onomatopeic for something a rickety rackety carriage would do.

So our final version read: Hos bos hoste stopte. Dandytint schoen van dandy Boylan sokken hemelsblauwe klokken daalde licht neer op aarde $(D / B \& H 333)$. But even this one is capable of being improved upon. If we changed the order of the last part of the sentence, and make it into daalde licht op aarde neer, we would have a very slight but noticeable allusion to a Christmas song in which Jesus, the saviour of lonely women, descends on earth. Something to keep in mind for the fourth impression.

Bald deaf Pat brought quite flat pad ink. Pat set with ink pen quite flat pad. Pat took plate dish knife fork. Pat went. (11.847)

Bald Pat at a sign drew nigh. A pen and ink. He went. A pad. He went. A pad to blot. He heard, deaf Pat.' (11.822) 


\section{WHY WE NEEDED A THIRD DUTCH TRANSLATION OF ULYSSES}

Monosyllabism seems to be the leading stylistic feature in these musical sentences. Curiously, Vandenbergh $(324,323)$ as well as Claes \& Nys (297) follow their master's lead in the first (later) sentence, but release the leash in the second (earlier) one. They start with the Kale Pat, a word order and a lengthening of the adjective which is required in Dutch, as a grammatical rule, but what are rules if you can't break them? And you'll have to break them here: you have to do it wrong to do it right. To do justice to the monosyllabism we introduced two proverbial expressions for Pat's portrait: the bald nit (de kale neet), for someone who is very bald (or poor), and the deaf pot (potdoof), for someone who is as deaf as a post: Neet pot Pat bracht zeer plat blok inkt. Pat deed bij inkt pen zeer plat blok. Pat nam bord schaal mes vork. Pat ging. And: Op een wenk schoot neet Pat toe. Een pen en inkt. Hij ging. Een blok. Hij ging. Een blok met vloei. Hij had pot Pats oor. (D/B\&H 328)

Lenehan round the sandwichbell wound his round body round. (11.240)

Diverse problems of different natures attack the unwitting, witless Dutch translator here. He already had to choose a word for the discovery of the Earl of Sandwich on his eponymous islands in the South Seas, about which later. Next we have the unusual word-order, in English: you would expect first the "round the sandwichbell" part. Vandenbergh does justice to it, by leaving the English word order untouched, which gives an equally unusual feel in Dutch, whereas Claes \& Nys again show succinctly their irrepressible will to normalize, which seems second nature to them: they revert to the usual Dutch subject-verb word order.

Vandenbergh (304): Lenehan om de stolp met sandwiches kronkelde zijn ronde lichaam rond.

Claes \& Nys (279): Lenehan wond rondom de sandwichstolp zijn ronde lichaam rond.

Though it clearly says (D/B\&H 309): Lenehan rond de broodjesstolp wond zijn ronde lichaam rond.

They lay, were read quickly and quickly slid, disc by disc, into the till. (4.183)

Vandenbergh as well as Claes \& Nys, in their persistent efforts to domesticate out-of-the-way words, translate the discs as if it said "coins". In Dutch a coin is 'een munt' or muntstuk, but if you say stuk, it will be clear as well, and the reader doesn't have to wonder why Joyce wrote the sentence in the first place. Plus, stuk voor stuk, which is an ordinary expression for "one after the other" will now acquire an overtone, an extra, literal meaning, which will give a frisson of eleoquence to the expression. Translating Joyce $=$ adding overtones.

Vandenbergh (71): Daar lagen ze, werden snel geteld en snel, munt voor munt, in de geldla geschoven.

Claes \& Nys (67): Daar lagen ze, werden snel geteld en snel, munt na munt, in de geldla geschoven. 
Bindervoet \& Henkes (73): Ze lagen er, werden snel geteld en gleden snel, stuk voor stuk, in de kassa.

A smile of light brightened his darkrimmed eyes, lengthened his long lips. (7.560)

Why not translate "a smile of light" as een lach van licht? Which sounds as Joycean as the English. Vintage Joycean almost. No, Vandenbergh and Claes \& Nys again normalize and wreck the sentence on their Procrustes bed:

Vandenbergh (155): Een lichtend lachje ...

Claes \& Nys (145): Een lichtende glimlach ...

Sparkling bronze azure eyed Blazure's skyblue bow and eyes. (11.394)

Apart from the musicke to be transposed into clogdanceable Dutch, there is the probeloom, how to make brons, which naturally comes as an adjective, into a recognizable substantive here. Because, if (as Vandenbergh and Claes and Nys did), you start with Sprankelend brons, the first thought is of a church steeple on which the sun shines. Solution: translate it as Sprankelbrons. Next obstacle is the fact that the entire sentence is an intricate knot of alliterations, assonances and rhymes in a compulsive jaunty rhythm. Vandenbergh and Claes \& Nys act as if neither rhythm nor rhyme were any of their concern:

Vandenbergh (309): Sprankelend brons lazuuroogde naar Blazuur's hemelsblauwe das en ogen.

Claes \& Nys (284): Sprankelend brons azuuroogde naar de hemelsblauwe das en ogen van Blazuur.

Our try, to reenact the sentential concertina: Sprankelbrons azuurblikte naar Blazuurs hemelsblauwe strik en blik. (D/B\&H 314)

The conclusion must be that Vandenbergh as well as Claes \& Nys have mistook the Sirens of this episode for the sirens of factories, firewagons and freighttrains. In all too many instances they turn a deaf ear to the most basic characteristics of this chapter, its rhymes and rhythms, and throw the musicality of Joyce to the wind as if it were a discardable accidental, instead of the very core of the accomplishment. Improvement here is very much called for.

\section{The Sandwich passage revisited}

The famous "Sandwich" passage $(8.741 \mathrm{ff})$ has already given rise to a complete and utter issue of Scientia Traductionis (n.8, 2010), with fine, ruminating, nutritious sandwichian articles by Erika Mihálycsa, Ástrádur Eysteinsson, Scarlett Baron and Jolanta Wawrzycka. The passage was also on the menu of the Transworkers in Zürich, so we are treading on well-trodden ground here. Unfortunately, we will have to dispense with general thoughts about the science or the art of translating, except in passing, not because we are theoretical refuseniks, but because we lack, as mere tillers of the field, the faculty of metalingual reflection on our own beautiful but laborious handiwork. We're not scholars, just practitioners. But no harm, we have better minds to backup our dab- 
blings: the gentle reader is referred to the articles in the Scientia Traductionis already referred to $($ n. 8,2010$)$.

\section{Sandwich?}

The word sandwich, as Jolanta Wawrzycka engagingly recounts in her "Sandwich on a Mission" article (Scientia Traductionis 8), was first put to paper - according to the Oxford English Dictionary - in 1762 by Edward Gibbon in his diary, but the sandwich itself apparently was invented in the first century B.C. by rabbi Hillel the Elder, who sandwiched a mixture of chopped nuts, apples, spices, and wine between two matzohs to eat with bitter herbs at Passover. In Dutch, the first mention of a "sandwich" is in the magazine Neerlandia, which was devoted to the propagation of pure Dutch. In a 1917 issue it commented ironically on the use of foreign (mainly French) words by young ladies, one of whom is pictured biting with gusto in a sandwich: lachte Vivette en beet smakelijk in een sandwich. A piece of bread with something on it, or in between it, can be called in Dutch a bolletje, a broodje, or a boterham - and nowadays of course also a thoroughly dutchified sandwich. (Were the English Dutch?)

But! For Bloom this simple word is the beginning of a chain of associations along the tracks of a folk riddle, some wellknown folklore that Joyce was so good in picking up and eager to pass on. The riddle consists of two questions and answers, and the first pair is: "Why should no man starve on the deserts of Arabia?" Answer: "Because of the sand which is there." It turns out that the word sandwich alone is already a pun here! Bloom is reminded of the riddle upon seeing the sandwich. So the sandwich, in another language, should be able to set off the otherlingual Bloom as well thinking of some folky, children's bit of punning, invented or real.

The answer to the first riddle is so deep inside Bloom's head that it can't even be picked up by the device of the interior monologue. The entire pun is contained in the one word "sandwich," but the answer to the second riddle we get in print. The question is: "How came the sandwiches there?" Answer (in Bloom's mind): because Ham and his descendants mustered and bred there".

\footnotetext{
${ }^{1}$ It was Fritz Senn who first uncovered the origin of Bloom's sandwichian thoughts (see: GIFFORD, Don \& SEIDMAN, Robert J. Ulysses' Annotated: Notes for James Joyce's Ulysses. Berkeley: University of California Press, 1989, 698 p.). The riddle itself appears from around 1888 on in compilations of humorous sayings - but it was probably already current for many long years, maybe even a century. It is said, for instance, that one of the reasons that Richard Whately, the cranky protestant Archbishop of Dublin from 1832 to 1863, was so unpopular - in contrast to other cranks in Ireland, who were generally well appreciated - "touched" they were called - was on account of his penchant for schoolboy conundrums like the sandwich riddle (SOMMERVILlE-LARGE, Peter. Irish Eccentrics. Dublin: The Lilliput Press, 1990 [1975], 111 p.). In 1905, we find the conundrum in a Dutch publication for the benefit of students of the English language: BERRINGTON, Benj. S. \& BERRINGTON, John S. English Riddles, with Explanations and Notes in Dutch. Purmerend, J. Muusses, 1905. The notes to item 62 (the first question) explain the meaning of the words starve (van honger sterven), desert (woestijn), and the curious contraptions called sandwiches (dunne sneedjes bood met vleesch er tusschen): thin slices of bread with meat in-between. Perhaps we can make Bloom ponder in Dutch, as translation for "Sandwich?" (of course in a modernized spelling): Dunne sneetjes brood met vlees ertussen?
} 


\section{ERIK BINDERVOET \& ROBBERT-JAN HENKES}

Translators tend to hate puns, because they slow them down and sometimes bring them to a grinding halt: they have to stop and think for a long long time. (If only they thought as much about the non-puns.) The pun is trite of course, but the trite and trivial are among the hardest things to transfer. If a translator manages to make a pun that is just as childish as the original, he runs the risk to be blamed for it. The translator rarely is accorded the benefit of the doubt that the author does get, Fritz Senn summed up the dilemma. The task is to find or create a puzzle that you can imagine kids tell each other in the playground and afterwards shout out: "Stoopid!"

The new German translator-reviser came up with the ur-German Hans Wurst as a stand-in for Ham. The Hungarians split the joke in two: one sentence is about eating and one makes the references to the biblical figures. Now our doubledutch language happens to stand with more than one foot in the English marshes: Dutch is a full cousin of English. Only in Dutch and English ham is "Ham" (an older variant of the Biblical "Cham") and "ham". Even our proxissimost Flemish bloodbrothers call the porky meat not ham but hesp! No other language but the Dutch and English can combine Noah's son and the nonkosher, non-halal sandwich filling.

Using our own peculiar notion of boterham, which means sandwich but literally translates as "butter-ham", Bloom may now think in Dutch: Boterham? Het botert niet tussen pap en Ham, want ham was broodje nuchter. Literally backtranslated: "Sandwich. It is not buttering (= going well) between dad (pap = dad, but also porridge) and Ham (Noah's son and the meat) because Ham was sandwich sober (idiomatic Dutch for as sober as a, as a, well, sandwich)." This is not an authentic Dutch children's riddle from the days of lore and yore, but it now has the appearance of it. We fake it, and this perfecty justifiable translator's strategy of faking frequently came up during the workshop. You can almost hear the reader shout out, "Ugh, what a lame joke!" Which only means that he gets the joke and that the translator has succeeded in his mission. Did our predecessors succeed?

Vandenbergh (200): Ham en zijn nazaten zijn daar bijeen en fokken maar verder. Not a pun in sight, it just literally says what it says: "Ham and his descendants are there gathered together and do nothing but procreate." The first translators didn't know any better, they didn't realize that it was a standing joke, they often didn't even see the joke.

Claes \& Nys (184): Ham en zijn zonen daar, hebben boter op het hoofd. "Ham and his sons over there, have butter on their heads." Having butter on one's head is idiomatic for being a hypocrite. Butter here fits the context, but you can hardly call it a pun, because the accusation of being hypocrites lacks any reason or context. Why should Ham and his sons be hypocrites?

Not satisfied with our solution, we returned to the Good Book, and read about Ham, who saw his father stretched out stone drunk and stark naked, and fled the crime scene of shame. Could this story be more highlighted than the non-committal "they didn't get along well" that we had now? We tried, punwise and primitively foolishly, to brush up the Biblical reference some more, in order to be free to muck about in the second part of the sentence. Phrases to be used: ' $m$ smeren (double meaning: to put butter on and to run away); blootvoets (barefeet), which can be paranomaniacally metamorphosized into broodvoets, in which we have bread too, "breadfeet" as it were - and the 
botervloot, the famous container for butter on the table, which also contains the word for naval fleet, vloot, and almost the ships too (schepen, or boten) if you change one letter and make a botenvloot out of the botervloot.

So with jigsawing and dovetailing we ended up with: 'Ham zag zijns vaders naaktheid en smeerde 'm broodvoets in een botenvloot.' (204-5) Ugh! What a lame joke! But in the end we might say, in punnylingual cases like this, it surely paid off to have translated Finnegans Wake before Ulysses.

Potted meats. What is home without Plumtree's potted meat? Incomplete. What a stupid ad! Under the obituary notices they stuck it.

Indeed. What a stupid ad. In spite of many international Interpol search warrants, this advertisment still hasn't been found out in a newspaper of around 1904. A rare example of Joyce inventing instead of stealing and appropriating? How to translate lame jokes, is also a subject worthy of a workshop. In any case it has to rhyme and to run lamely. The two previous Dutch translations have neither rhyme nor rhythm, and miss the point completely. Which is a pity: here they had the chance to translate a lousy English rhyme into a lousy Dutch rhyme: grist to their mill, you'd think. Wrong. grof gebrek.

Vandenbergh: Wat is het thuis zonder Plumtree's Potten-vlees? Een jzonder.

Claes \& Nys: Wat is uw huis zonder potje Plumtree Paté? Niets bi-

Bindervoet \& Henkes: Hoe uw huis zonder pot paté van Plumtree heet? Incompleet. Literally: "How your home is called without Plumtree's potted meat? Incomplete." Almost sounds like the real thing!

All up a plumtree.

Gifford: "Slang for cornered, done for; or, trapped in an unwanted pregnancy". Though Dent says, rightly, that the expression is "up a tree", the plum being Bloom's punning addition. The important thing here is to do something, anything.

Claes \& Nys: Allemaal de pot in, is just what it says: "all of them into the pot," and nothing more.

Vandenbergh has the eloborate: De aap is wel in de pruimenboom gelogeerd, deriving from the Dutch expression "being in the monkey lodged" that is landed into trouble against expectations, with the pruimen (plums) added for good measure. Velly nice! But a bit long. And - to tell the truth - a bit too construed: not a pun which would spring naturally, of its own accord, to mind, even a mind with such a good ear for bad slogans as Bloom's.

We opted for De pot op kunnen ze, in which the pot is a WC and the expression meaning that they can jolly well go and befoul themselves. Bloom's fruity extension now applies both to dead creatures being potted and to the people that make such a bad ad and those who put it under the obituary notices.

Dignam's potted meat. Cannibals would with lemon and rice. White missionary too salty. Like pickled pork. Expect the chief consumes the parts of honour. Ought to be tough from exercise. His wives in a row to watch the effect. 
"His wives in a row": in a line or in an argument? Or both? Another impunnible poss? To make the best of both worlds, we came up with: Zijn vrouwen in het gelid, which is "in line" in a more or less military sense, and gelid is a word reminiscent of "lid" in all senses of "member" including the socalled third leg. Not the same, no, but appropriate in this context.

Neither Vandenbergh nor Claes \& Nys suspected a catch "in a row", and to tell the truth, neither would we if Erika Mihálycsa hadn't brought it up. Which, incidentally, highlights another important characteristic of translating Ulysses: it is a collective effort. It is not a book that can be tackled without consulting many people, which is exactly what Claes \& Nys didn't do. They never showed their noses at gatherings, never asked any Joycean about certain cruxes, and when a new edition came out of their translation (eight or so, to date) they never took the opportunity to change their original solutions, something which John Vandenbergh incessantly did in his eight editions from 1969 to 1994. The real ideal sleepless translator in this respect may very well be the Danish oversatter Mogens Boisen, who completely retranslated his own translation twice: he first translated Ulysses in 1949; overhauled it thoroughly in 1970, and brought out another major revision in 1980. Ulysses was, Wikipedia mentions parenthetically, et verk, Boisen aldrig holdt op med at arbejde med - a work Boisen never stopped being busy with.

There was a right royal old nigger. Who ate or something the somethings of the reverend Mr MacTrigger.

The only thing a translator hates more than puns are poems in a prose text. Is he up to the task? Is he equipped to translate poetry as well as prose? Often the two worlds are strictly divided, and very seldom the twain meet. In Dutch, the n-word is the same, only with two k's instead of g's. But what to do with the name?

Vandenbergh: de eerwaarde MacTrigger, leaves the reverend his English name, which is a bit strange for an irreverent piece of verse: especially names are telling elements in ballads, broadside or otherwise.

Claes \& Nys inexplicably change the name to Flikker, "Faggot", which is much too toothclenching tight for the purpose of a harmless scurrilous piece of limerick. Because of the rhythm, they had to change the denomination of the good missionary from a pater (Catholic) into a dominee (protestant). The Belgian twosome prided themselves on their knowledge of Catholicism, and chided Vandenbergh for his lack of it, but here they take very great liberties with their not-too-great knowledge of protestantism...

We left the Irish Mac, but made him into a certain MacKrikker, in which the verb to krik shines through, which is a quite harmless, even euphemious and decidedly un-nasty synonym of to If You See Kay.

With it an abode of bliss.

The rest of the Plumtree ad. Without Plumtree home is incomplete, with it an abode of bliss. Claes \& Nys pick up the rhyme at this spot: Maar met, een hemel hier beneê. ("But with, a heaven here downunder.") 


\section{WHY WE NEEDED A THIRD DUTCH TRANSLATION OF ULYSSES}

Vandenbergh is as literal and non-advertorial as he is in the first part of the advert, with his Maar met, een paradijs op aarde. ("But with, a paradise on earth".)

We managed to rhyme where the English rhymes, so here we can finish off with a faithful remake of the intended contrast without-with: Maar $u$ weet zich gezegend met. ("But you know yourself blessed with.")

Lord knows what concoction.

Yes, there's an obvious cock sticking out in the word "concoction". (Madonna: "Why is a crucifix sexy? Because there's a naked man on it.") Not seen by Vandenbergh, nor by Claes \& Nys. So it couldshouldwould be and is now: Joost [= the Devil] mag weten wat er allemaal onder het lid zit. Dutch lid is English "lid" (for closing a pot, potted meat for instance), and the member above referred to as well.

Cauls mouldy tripes windpipes faked and minced up. Puzzle find the meat. Kosher. No meat and milk together. Hygiene that was what they call now.

The last sentence, "Hygiene that was what they call now", is an instance of what Fritz Senn named, at the Transwork sessions, "mind's grammar". First the major thought, with the grammar trailing after, in the right mind order. It's almost an ourobouros sentence like this, that can start again after the last word.

In line with their self-proclaimed nobel task to simplify Ulysses, Claes \& Nys make a sober, informative correct sentence (Hygiëne heet dat nu.), leaving the reader more than puzzled, and asking himself: Why on earth would Joyce write down something so incredibly bland? (Answer: He didn't!)

Vandenbergh also translates with the flat-iron: Hygiëne zouden ze het nu noemen.

Why not, as it says, and which is perfectly readable and understandable: Hygiëne was dat wat ze 't nu noemen. Which we have now, but (note to selves, for the fourth edition): it could even be without the elided article 't: $\mathrm{Hy}$ giëne was dat wat ze nu noemen. In which all the words of the "normal" sentence are there (dat was wat ze nu hygiëne noemen), and it really is a sentence that bites its own tail: Hygiëne was dat - wat ze nu noemen hygiëne was datwat ze nu noemen etc.

Yom Kippur fast spring cleaning of inside. Peace and war depend on some fellow's digestion. Religions. Christmas turkeys and geese. Slaughter of innocents.

"Slaughter of innocents" is a, what we call Bloomism, or unintentional contamination, born out of forgetfulness of the main hero, the fallible protagonist, aka the unreliable narrator. Herod perpetrated the Massacre of the Innocents, which indeed was a slaughter, but differently called. Fritz Senn holds that the "slaughter" may not be totally strange and wrong, but still.

In Dutch, the episode, also depicted by Breughel the Elder and PeterPaul Rubens, is variously called Moord op de Onnozele Kinderen, or Kinder- 
moord te Bethlehem. But this can't be used here, because the innocence of the turkeys is what triggers Bloom's thought.

Both Vandenbergh and Claes \& Nys miss the Bloomism and translate Kindermoord te Bethlehem - "Children's Murder at Bethlehem" - without any more ado about anything, dustbinning the reference to the innocence of the turkeys - no young or small ones either - that lose their life at the Christmas table.

A Joycean translation only starts with finding the right expression. Subsequently it has to be manipulated in some way to get the Joycean effect. Bloedbad der onnozelen captures Bloom's misremembrance of things past, present and pluterperfect, and leaves the 'innocents' intact and in fair play. It is not the exact Biblical reference, but the tone is Biblical enough: sometimes you have to fake it to get the tone right and recreate the effect.

Eat drink and be merry. Then casual wards full after. Heads bandaged.

A Biblical allusion: Ecclesiastes 8 divided by 15, has, in the Protestant, 17th century standard Statenvertaling: Daarom prees ik de blijdschap, dewijl de mensch niets beters heeft onder de zon, dan te eten, en te drinken, en blijde te zijn...

Vandenbergh: Laat ons eten, drinken en vrolijk zijn. (Uses a different Bible translation, probably.)

Claes \& Nys: Eten, drinken en blijde zijn.

Curiously, Bloom's allusion loses the preposition "to", in the phrase "to eat, and to drink, and to be merry", making it more of an admonition or even an order than a list of three infinitives, which it is in the Bible. A translation should take this hortative undercurrent into account: Eet drink en weest blijde.

Cheese digests all but itself. Mity cheese.

"Mity cheese" was in the 1922 edition still the ordinary "Mighty cheese," as a result of some overzealous printer correcting Joyce's illiterate mistake. Hans-Walter Gabler in 1984 restored Joyce's intention. "Mity" it should be. But what does it mean? And what more does it mean? And why? In Ulysses, everything means at least two things, or we should say, is written at least for two reasons, an obvious one and a hidden one. Translators often don't look any further than their nose is long, and are already chuffed and glugged when they get surface layer right.

Mity maybe because of the mites which devour the cheese they live in? Yes sirree: "Cheese mites [...] are best known for their occurrence in cheese, in which they gnaw small holes. [...] For many cheeses the presence of mites is highly undesirable, but there are some cheeses in which a culture of cheese mites is introduced for example to Altenburger cheese to impart a characteristic 'piquant' taste." (http://www.the-piedpiper.co.uk/th7g.htm) These things you have to know as a Ulysses translator, or should at least be not too lazy to look up.

In the ultra-exclusive, almost sectarian internet forum Ulysses For Experts, Harald Beck discovered a little verse that may well be on Bloom's mind, one which he may have picked up in a cooking book or on a household kitchen calendar of some kind. It is an "old adage" which runs: 


\author{
Cheese is a mity elf, \\ Digesting all things but itself
}

Which still leaves the question unanswered, is "mity" an ancient spelling of "mighty" or isn't it? We may picture Bloom remembering the old adage precisely because of the equivocation. The word works both ways in the characterisation of the cheesy comestible.

Vandenbergh, translating in 1969, never knew about the "mity", so he is excused.

Claes \& Nys exclusively go for the mites: "Mijterige kaas."

Sidestepping to the Russian translation, Hinkis \& Horuzhij (Horuzhij finishing the work of an untimely deceased Hinkis) ${ }^{2}$, construct a nice little slogan with a pun it it: byl sukh, stal syr, will be read as "was dry, became wet," but the last word syr meaning "cheese" at the same time, the sentence can be read as "was dry, became cheese," as well. The suggestion that it "amounts to incomprehensibility" (Wawrzycka, "Sandwich on a Mission," 181) has to be amended.

Not knowing whether the "mity" is "mighty" in an old-fashioned disguise, or refers to the gnawing insect, we would say that anything that tries to combine both, or does something more with the two words than merely translate them, is commendable. If "mity" was only "mighty", we could spell machtig as magtig, as it used to be spelt in the dear old days beyond recall when there weren't any preferred spelling guidebooks. But magtig has no other connotations but an oldfashioned machtig. We grappled and finally decided to have Bloom expanding on his own thought. We allowed him to think: Mijterige kaas. Magtige kaas - as if these were the words of the old adage he remembers reading on Molly's kitchen calendar.

The new French translation (Aubert et al.) has Fromage qui marche tout seul, which, backtranslated would be something like "fast runny cheese." In Dutch, we could come up with Gaat die kaas, contaminating gatenkaas (cheese with holes, very popular in Holland) with "there goes that cheese." Worth contemplating for the fourth edition.

Ideally a translation does the same for the target language as the original for the source language. If a reader is wondering what's all this fuss about Ulysses, what's so special about it, then sometimes the reader is to blame when a book and a head come together and produce a hollow sound, it is not necessarily the book's fault - but equally the translation can be less faulted. As Kurt Tucholsky famously remarked when Goyert's translation of Ulysses came

\footnotetext{
${ }^{2}$ Translating Ulysses in Soviet Russia was certainly risky business. The first fragments, translated by V. Zhitomirski, were published in 1925, and went by unnoticed. In the 1930s there were two serious attempts at a full translation: Valentin Stenich published chapters 4-6 in 1935 and was arrested and killed in 1937. A group of translators published chapters 1-10 in 19351936; the main translator, I. Romanovitch was also arrested and killed. Later, fragments were translated by A. Livergant (1982) and, in relative safety abroad, by I. Pomerantseva (1985) and I. Shamir (1986). Viktor Aleksandrovitch Hinkis, the co-translator of the complete Russian translation, died in 1981, 51 years of age (Dzhejms Dzhojs, Uliss, Moscow 1993, 553).
} 
out: "Either a murder has been committed, or a corpse has been photographed.",3 Often the efforts of the benevolent reader are frustrated by the translation. Whereas translators of Ulysses get the golden opportunity to pepper and spice and boost their own language with all the vitality and fun of the Joycean language and vice versa, this is an opportunity the two previous translations of Ulysses sadly missed.

"Every sentence is an event in Ulysses," Fritz Senn summarizes, "and the least a translator can do is take risks, because Joyce took risks as well." And that is exactly why we needed a third translation.

Erik Bindervoet \& Robbert-Jan Henkes rjhenkes@xs4all.nl ebindervoet@hetnet.nl Freelance translators and scholars, Amsterdam

\footnotetext{
3 In inimitable German: TUCHOLSKY, Kurt. Schlußurteil über die Übersetzung: Hier ist entweder ein Mord geschehen oder eine Leiche photographiert. Die Weltbühne, Wochenschrift für Politik, Kunst, Wirtschaft, Volume 23, 1927 (p.790 in the 1978 reprint).
} 